\title{
Access to Food, Dry Season Strategies and Household Size amongst the Bambara of Central Mali
}

\author{
Camilla Toulmin
}

The Bambara village of Kala lies on the northern frontier for regular crop production in Mali (see Map). With a long term mean rainfall of $600 \mathrm{~mm}$ per year, this region forms part of the southern Sahelian zone. Rainfall is concentrated in the three months from July to September and intensive work in the fields must be done during this short period to ensure a harvest. Rainfall is highly variable in its distribution within the year, between neighbouring villages in a given year and from one year to the next. Expected rainfall levels have been falling over the last 20 years; levels ranged from 350-450 mm per year over the period 1980-83 before falling to the exceptionally low total of $250 \mathrm{~mm}$ in the drought year of 1984 .

Farmers have adapted to this risky environment in several ways. Two millet varieties of different cycle length are grown and it is rare for both varieties to fail in the same year. Oxen phoughteams have been widely adopted as they enable farmers to cultivate a very large area of land per worker. Surplus grain is stored in granaries or invested in livestock - cattle, sheep, goats, horses and donkeys - which can then be sold in years of food shortage. Within Bambara society, there are also a variety of mechanisms through which grain is redistributed (described in greater detail below, which help individual households suffering crop failure.

The lower rainfall levels of recent years have brought a shift in resources towards an increase in area under short cycle millet, as this has a greater chance of reaching maturity during the short growing season. However, this variety of millet only performs well on manured soils. Farmers have therefore needed to gain access to more dung in order to increase the area they cultivate with this crop. Much of this dung comes from relationships of exchange established during the dry season between farmers and livestock-owners, the latter gaining access to water for their stock from the farmer's well in return for stabling their herds on the farmer's field each night. Wells have become crucially important assets to farmers if they are to produce a regular grain surplus. Diagram 1 shows the growth in private wells dug in the village, from which it can be seen that by 1981 there was a total of 29 private wells. The dry season of 1983 witnessed a further 16 wells dug. However, these wells are far from evenly distributed between the 29 households in Kala. The largest domestic groups not only were the first to get a well dug but they have also dug second and third wells, thereby gaining access to large quantities of dung for their fields. This strong correlation between household size and levels of asset-ownership is discussed further below.

While the climate imposes a heavy risk on producers, due to rainfall variability, there are also other large risks to which people are subject and against which they attempt to protect themselves. This second class of risk is largely demographic in nature and consists of high levels of mortality, paticularly among children, varying levels of fertility and the vulnerability of all producers to sickness and disability. Many Bambara live in large, complex domestic groups containing men who share a common ancestor, often as many as five or six generations in the past, living with their mothers, sisters, wives and daughters. Men continue living and working together over several generations before the household divides, giving these large groups a solidity and permanence which transcends the importance of any particular individual.

\section{The Large Bambara Household}

Table 1 presents data on the distribution of households by size in Kala, from which it may be seen that 85 per cent of the population live in complex households, the mean size of which exceeds 24 people. These are very much larger groups than are found in other West African village studies and this paper will outline both the advantages which these large groups reap and the internal structure of such groups which allows them to minimise conflicts of interest between their members. Large households face certain advantages in crop and livestock production which include:

WDS Bulletin. 1986. vol 17 no 3. Institute of Development Studies. Sussex 


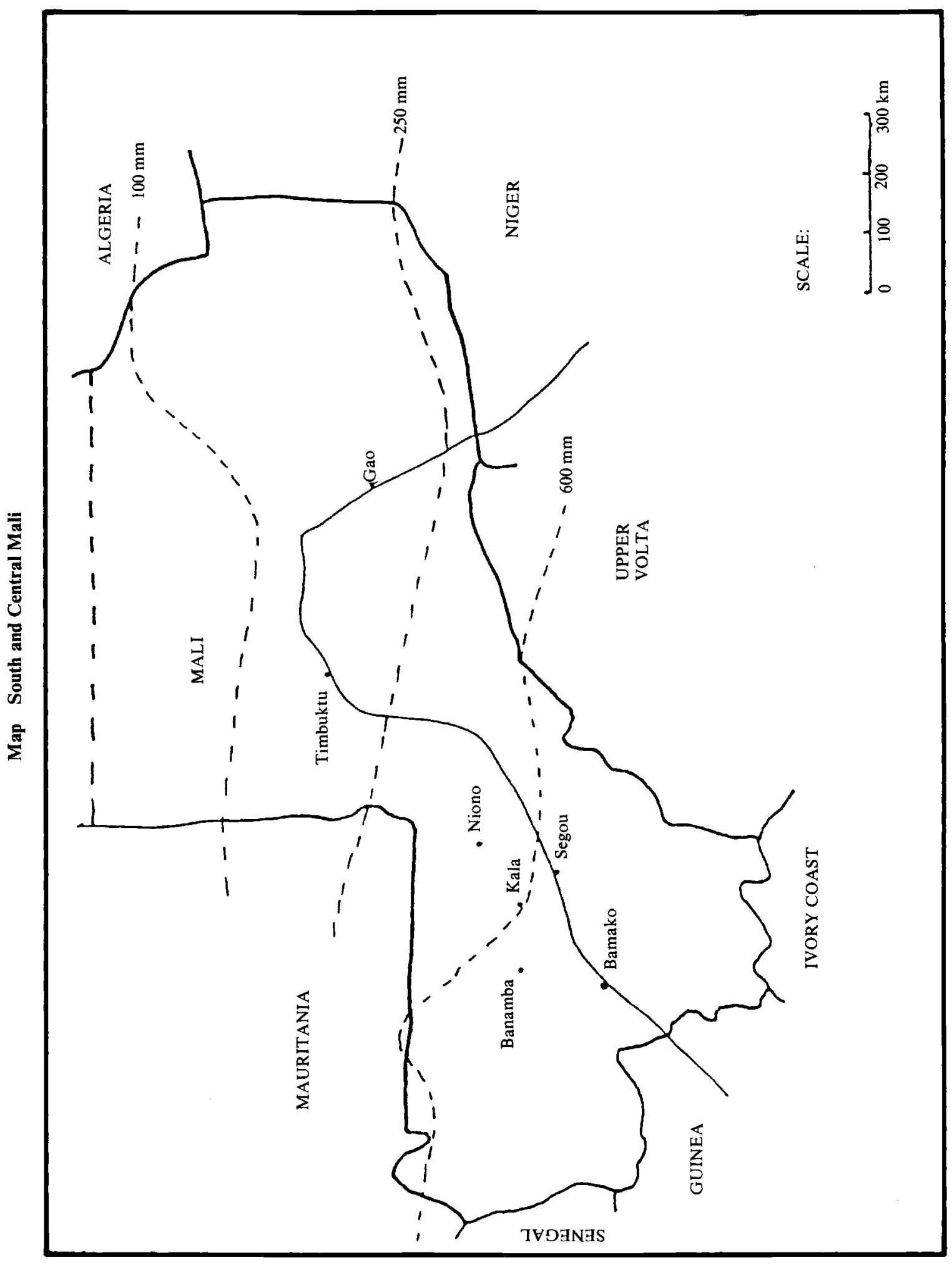




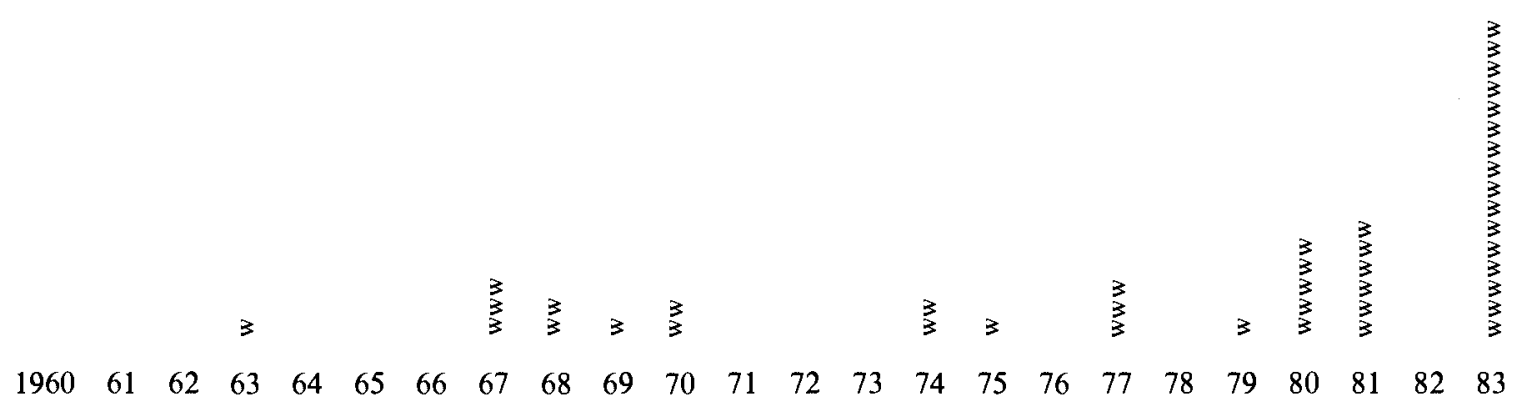

Number of Wells Dug by Households per Year

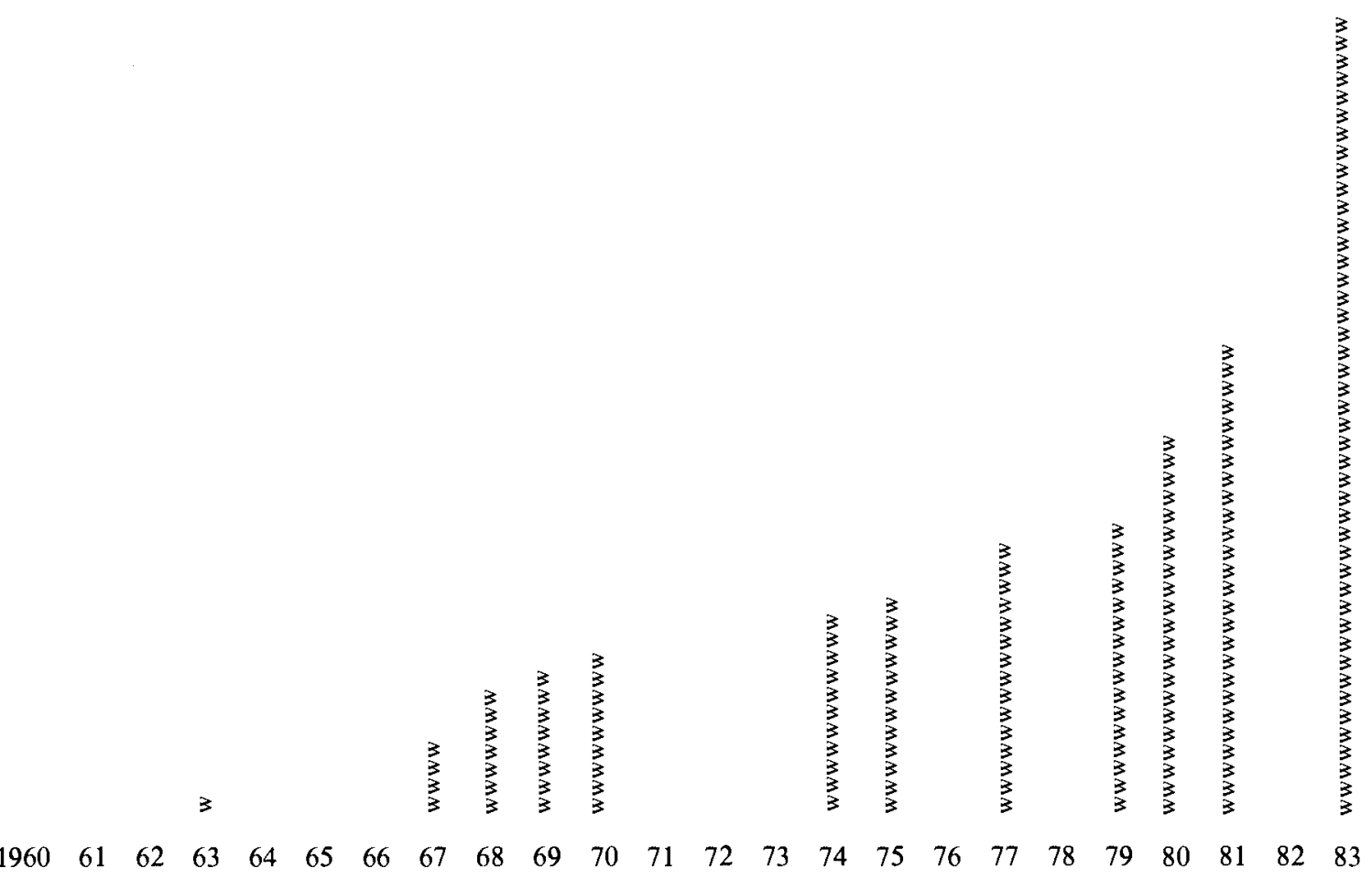

Cumulative Total of Private Wells Dug 
Mean Household Size by Type, Kala 1981

\begin{tabular}{lcccc}
\hline & $\begin{array}{c}\text { No. of } \\
\text { hhs. }\end{array}$ & $\begin{array}{c}\text { \% of total } \\
\text { hhs. }\end{array}$ & $\begin{array}{c}\text { Mean size } \\
\text { of hh. }\end{array}$ & $\begin{array}{c}\text { \% of total } \\
\text { population }\end{array}$ \\
\hline Complex Households* & 19 & $66 \%$ & $\begin{array}{c}23.8 \\
(12.9)\end{array}$ & $85.6 \%$ \\
Simple Households** & 10 & $34 \%$ & $\begin{array}{l}7.6 \\
(3.8)\end{array}$ & $14.4 \%$ \\
Village Total & 29 & $100 \%$ & 18.2 & $100.0 \%$ \\
\hline
\end{tabular}

Note: * Complex households are those containing more than one married man.

** Simple households contain either a single married man or unmarried men with a widowed mother.

Figures in brackets denote the standard deviation.

Table 2

Distribution of Wells, Workoxen and Breeding Cattle Holdings: Kala 1981

\begin{tabular}{|c|c|c|c|c|c|}
\hline \multicolumn{6}{|c|}{ Breeding Cattle Holdings } \\
\hline & 0 & $1-10$ & $11-20$ & $21-40$ & $>40$ \\
\hline 0 & $2^{\circ} 1 *(2.6)$ & & & & \\
\hline $1-4$ & $4^{\circ} 5^{*}(4.9)$ & $1^{\circ} 5^{*} 1^{* *}(5.1)$ & & $1 * 1 * *(7.9)$ & \\
\hline $5-8$ & & & $2 *(10.7)$ & $1 *(11.6)$ & $1 * *(14.9)$ \\
\hline $9-12$ & & & & & $1 * 1 * *(16.1)$ \\
\hline $13-16$ & & & & & $1 * 1 * *(16.9)$ \\
\hline
\end{tabular}

Note: Figures in the matrix refer to the number of households. ${ }^{*},{ }^{* *}$ refer to those households with no well, one well or two wells. Figures in brackets are the mean number of household workers for that element in the matrix.

\section{HOLDINGS OF WORK OXEN}

(a) the diversification of income sources, thereby reducing risk to overall income. In the rainy season, women from larger households have time to plant a small plot of grain which provides a supplement to household grain supplies. In the past few years, several households have also detached one member to engage full-time in petty trade during the farming season, a period when village traders have a near monopoly on the supply of goods in the village. Out of the six permanent trading businesses, five are in the largest and richest households for whom it represents an additional source of income and avenue for wealth accumulation. In the dry season, labour is spread amongst a number of activities, some of which are essential to maintaining the household's farm and livestock production while; others represent an opportunity for the household and individual to supplement income from other sources. Women in households where they are not the sole woman in charge of the cooking can share the housework, leaving time free to devote to money-spinning occupations. Migration by several young men to town is easier for the larger households, since a few of their peers can remain behind in the village to water cattle and prepare for the next farming 
season. (b) economies of scale which operate in the process of generating a surplus for investment in productive assets. It is easier for larger households to finance investment in large indivisible assets, such as an oxen ploughteam, as they have at their disposal an absolutely larger volume of resources. Similarly, larger households have found it easier to invest in digging a well because they can mobilise their own labour force to get the well dug rather than having to hire a well-digger.

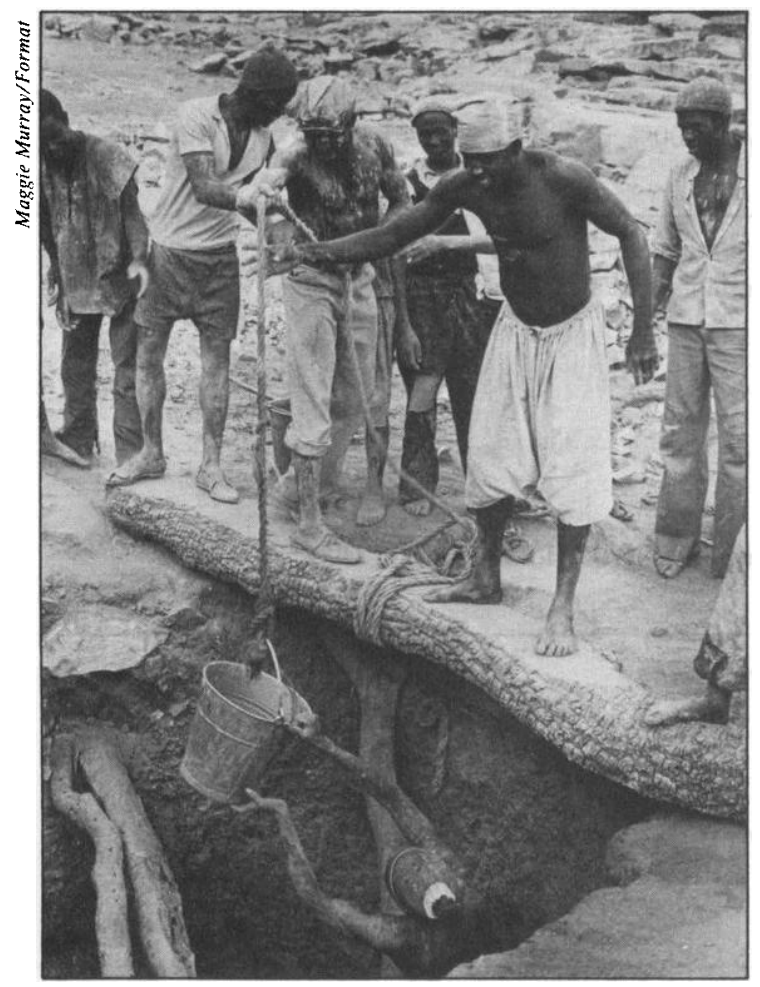

Constructing a safe-water well Dogon Region, Mali, West Africa.

Large households are also better able to protect their members from demographic risk; they are less vulnerable to the illness or death of one of their members and they are likely to exhibit less variation in dependency rates than a nuclear household. They can also safeguard the investment made in acquiring a woman as wife through the practice of the levirate, an institution whereby a woman is inherited by the younger brother of her dead husband. In a small household, there is less likely to be an inheritor present and the woman will pass out the household's control when she remarries.

The result of these advantages faced by larger households is that they can build up a larger agricultural surplus to be invested in assets such as wells, oxen ploughteams and a breeding cattle herd. Table 2 shows the distribution of the three main assets between households in Kala from which it may be seen that there is a strong positive correlation between ownership of the different assets. Household size increases regularly as one moves from the top left to bottom right-hand corner of the table. Small households are those most likely to be with neither a well, work oxen nor a cattle holding, whereas the largest holdings of these assets are associated with the largest domestic groups. In addition, larger households tend to be absolutely better-off, as may be seen from Table 3, in which cattle holding per household member is shown. This greater level of livestock wealth per person for the larger households gives them greater ability to finance tax and bridewealth payments and to purchase grain in years of poor harvest.

The advantages of large household size have been described above. The disadvantages likely to arise from the organisation and management of such a large group (such as labour-incentive problems and disputes over the allocation of labour time and other resources) are minimised by specifying clearly the rights and obligations of the individual to the joint estate. Typically these consist of each household member being required to work on the household's fields from the first sowing of grain in June or July until the harvest is finally stored in January. In addition to work in the field, women have domestic duties to fulfill and men must water livestock. Workers are allowed to retire from household production and to devote themselves to their own interests by their late forties or early fifties, women tending to retire earlier than men, the exact moment depending on the household's access to labour with which to replace them. In return for their labour, household members normally receive food, have their taxes paid and in the case of men, they can expect the household to finance much of their marriage expenses.

\section{Household Organisation by Season}

Bambara household production is markedly different in the two seasons of the year. The intensive farming season, during which household members work and eat together, is followed by less cohesive patterns of production and consumption once the harvest is stored and the dry season arrives. The Bambara language makes a clear distinction between the two patterns of organisation, the joint production for the household estate being termed 'foroba' while the individual pursuit and enjoyment of wealth is termed 'suroforo'. 'Foroba' means literally 'big field' and refers to the large field cultivated by the household as a whole. 'Suroforo' means 'night field' and describes the small plots farmed by individuals at twilight once 
Distribution of Cattle Holdings by Household, Kala 1981

\begin{tabular}{ccccc}
\hline Herd Size & $\begin{array}{c}\text { No. of } \\
\text { HHs }\end{array}$ & $\begin{array}{c}\text { Mean Herd } \\
\text { Size }\end{array}$ & $\begin{array}{c}\text { Mean HH } \\
\text { Size* }\end{array}$ & $\begin{array}{c}\text { Cattlef } \\
\text { HH member* }\end{array}$ \\
\hline$>40$ & 5 & 78.4 & 31.1 & 2.52 \\
$21-40$ & 4 & 31.3 & 22.0 & 1.57 \\
$11-20$ & 1 & 20.0 & 11.5 & 1.74 \\
$1-10$ & 16 & 4.1 & 9.7 & 0.42 \\
0 & 3 & 0.0 & 4.0 & 0.00 \\
Village mean & 29 & 20.8 & 14.6 & 0.94 \\
\hline
\end{tabular}

Note: ${ }^{*}$ Household size is calculated here using adult equivalents, in which those over 15 are taklen as 1.0 and those under 15 as 0.5 .

Table 4

Characteristics of Food Deficit and Surplus Households, Kala 1980 and 1981

\begin{tabular}{lcc}
\hline & $\begin{array}{c}\text { Deficit } \\
\text { households* }\end{array}$ & $\begin{array}{c}\text { Surplus } \\
\text { Households* }\end{array}$ \\
\hline $\begin{array}{l}\text { No. of HHs } \\
\begin{array}{l}\text { Mean HH Size } \\
\text { Mean No. of }\end{array}\end{array}$ & 15 & 14 \\
$\begin{array}{l}\text { Wells/HH } \\
\text { Mean No. of }\end{array}$ & 12.7 & 23.4 \\
$\begin{array}{l}\text { Cattle/HH } \\
\text { Mean Yield of } \\
\text { Millet/HH } \\
\text { Worker** }\end{array}$ & 0.6 & 1.3 \\
\hline
\end{tabular}

Note: *Deficit households were those that ran out of millet before the harvest in both 1980 and $1981 .{ }^{* *}$ Worker refers to an index aggregating those of different age and sex by a system of weights.

work on the household field is finished for the day. The 'forobal' harvest is housed in a single large granary managed by the household head and from which grain is taken for household meals, tax payments and certain other joint expenses. Small 'suroforo' granaries are found by each married woman's hut and the grain from these provides her with the means to cook the occasional special meal for her husband and children and the income for necessities and treats, such as clothing, soap, sugar and sweets.

Despite its roots in the distinction between the two kinds of field, the 'foroba'/suroforo' dichotomy applies in many other areas of Bambara life, such as livestock holdings, some of which are owned by the household whereas others are the property of a smaller group or of an individual. The basis for the division of activities, income and wealth between these two forms of ownership rests on household members having certain labour obligations to the joint household estate, after which they are free to pursue their own interests. In the dry season, once the millet is safely stored, there are few demands made upon the individual's time. Household duties are limited to watering the herd early in the morning and clearing new land, both tasks performed by young men, while women continue with their daily domestic tasks of fetching water, cooking food, caring for children and washing clothes. Once these tasks are accomplished, men and women can work on their own account. Men pursue a variety of activities which include fortunetellers, going on migration to town, weaving cotton cloth, hunting and making ropes. Women's sources of income consist of plaiting other women's hair, spinning cotton, dyeing cloth, collecting bush fruit and preparing snacks for sale. Both men and women also of ten have a petty trading business during the dry season.

\section{Eating Patterns by Season}

In the rainy season, food is prepared and consumed by the joint work-group, it being carried out to the field in mid-morning. The household does its best to ensure that people are properly fed during this time of intense physical exertion, as the future year's supply of grain will largely depend on the speed and care with which sowing, weeding and harvesting work is carried out. A hurried, of ten cold, breakfast allows the men and girls to leave the village soon after dawn to start work in the field. Women stay behind to prepare the midday and afternoon meals, before setting out around 10 a.m. with their bowls of thick millet porridge, 'to', its consistency being thought to provide the strength 
needed by those who spend the day weeding. In midafternoon, the workforce sits down to a calabash of 'dege', a thin fermented gruel, lightly spiced and mixed with a little soured milk if available. Most households prepare a hot dish of 'moni' porridge in the evening, a light meal with which to send the household to sleep. A few households however would have a second dish of 'to' prepared for the evening to satisfy their members appetite and keep up their enthusiasm.

Once the peak weeding season is over, the pace of activity slows. With the millet harvest safely stored in January, many people disperse to visit relatives elsewhere or go to towns to earn cash. Many households continue to provide meals each day but a thin millet gruel is substituted for the thick 'to' porridge at midday. Women take grain from their own stores to prepare an alternative dish for their own nuclear group, so that they can eat something more tasty than this thin, watery dish. Those households where grain is in very short supply aim to conserve their stocks during the dry season by a variety of means. People leave to work and stay in neighbouring settlements, thereby reducing the burden of feeding them on the household granary. Such households also shift onto women the task of finding enough food for immediate kin. In such cases, women's granaries change from being an alternative source of food to providing the basic food ration for those remaining in the dry season.

\section{Food Deficit Households}

Table 4 compares the characteristics of grain surplus and deficit households in the village of Kala. Deficit households are those which ran out of grain before the next harvest in both 1980 and 1981 . From this table, it may be seen that 15 out of the 29 households in the village suffered a food deficit in both years.

Many of these deficit households are of small size and own few productive assets. They have lower than average labour productivity because they have less access to dung and to ploughteam services, both of which are essential to ensure the regular production of a millet surplus. Often with not enough grain to eat, these households have been less able to invest in productive assets, such as wells, nor do they own cattle other than work oxen, which would be available for sale in years of food shortage. Certain of the households which ran out of grain early also had a very unfavourable ratio of consumers to workers, so that despite average yields per worker, the harvest was not large enough for the household's food needs. In one extreme case, the household had run out of food in May, before the end of the dry season. Part of this deficit was attributable to the household's general poverty - no well, ploughteam cattle or other livestock owned. However, the severity of the food shortage was due in large part to a major share of the previous harvest having been sold to finance the digging of a well using hired labour. The household opted for a period of grave food shortage in order to build up future productive capital in the form of a well which, it was hoped, would provide dung for the fields and raise yields of the short cycle millet. This household's food needs were met during the forthcoming rainy season by a variety of strategies which included sending the son to work for another household in exchange for grain, collection of bush fruit and begging of grain and bran from this and neighbouring villages.

\section{Access to Food}

The household's food needs are met from various sources, few farmers have stored grain from harvests in prior years from which grain was taken for household meals. Women's granaries provided a major addition to food stocks in many of the smaller, poorer households. The stocks held by elderly women are especially important in this respect as these women, being free from work in the household field, can cultivate a substantial field of their own. Apart from the harvest of private fields, women also acquire grain from harvesting and winnowing fees and from gifts received from relatives at harvest-time. It is common for men and women, but particularly the latter, to travel to neighbouring settlements at harvesttime. They help carry out the harvest and they winnow the grain, receiving in exchange a calabash of millet. Women's granaries can contain a considerable quantity of grain; while a busy young wife may have only $100-200 \mathrm{~kg}$ of millet, older, retired women often have more than $1,000 \mathrm{~kg}$ at their disposal.

Food supplies are supplemented for some by sending one of their family to work for another during the rainy season, the wages for this labour being paid in the form of several measures of grain.

Cash may also be used to buy grain, as when migrants' earnings are used to purchase sacks of millet or when assets have been sold. During several weeks of the dry season food may also be procured by collecting various bush fruit, such as bere (Boscia senegalensis) and baobab. Official systems of redistribution exist in the more Islamicised villages of the region, one tenth of the harvest being set aside as 'jaka', or tithe, to be given to other members of the community. In Kala, a similar proportion of the harvest is redistributed, though in a less formal manner. Women in Kala appropriate large quantities of grain at winnowing time, both for themselves and for payment of winnowing fees to those women helping them. Direct gifts between households are rare, a few cases occuring 
at major festivals when a particularly devout man made gifts of $30-40 \mathrm{~kg}$ to poorer neighbours. Lewis (1979) also notes the low incidence of such direct gifts in his study of a strongly traditional Bambara village to the south of Segou. He attributes the absence of such flows to the importance attached by villagers to egalitarian ideals and the consequent desire to avoid relations of dependence between poorer and richer households. If grain is channelled through women, help is given to poorer members of the community but at lower cost to men's pride.

The poorer households in Kala gained a significant proportion of their food needs from sources other than the previous harvest. However, while non-harvest sources play an important part, these households are often less able to exploit them fully. For example, many of these grain deficit households contain a single woman of working age who has little time to cultivate a field of her own. Women in the five smallest households were the only ones in Kala not to have a private field of their own. With their small workforce, the household can less readily send out of its members to work elsewhere during the farming season, in order to earn millet, without seriously affecting its own ability to farm. In the dry season, the daily demand for labour to water plough oxen limits how much time can be spent on migration and thus the amount of cash available from this source with which to purchase food. Larger households are better placed to tap the range of incomes available, as there is a sufficient workforce for some to remain in the village to perform essential dry season tasks while others can go off looking for work. The few assets owned by food deficit households also limit the cash which can be raised from their sale. Owning no cattle other than work oxen, these animals cannot be sold to buy food without diminishing the household's ability to farm. In addition, sheep and goats, largely owned by women, are usually few in numbers in these small grain deficit households, as few women can build up enough of a surplus to invest in these stock.

\section{Dry Season as Adjustment Period}

The dry season presents different opportunities to different households. Those which have had a poor harvest must both enable their members to survive during these months and generate sufficient income to purchase the food needed to farm the following season. Hence the common strategy of those in greatest distress is one whereby the compound empties once the meagre harvest is assessed and people scatter to pursue their luck elsewhere. By contrast, those in grain surplus households can use this period of relative freedom from household labour obligations to generate private income and accumulate their own sources of wealth.
In years of poor harvest, the strategy followed by a household depends on a number of factors, such as the extent to which other producers have been similarly touched, the ownership of livestock and the consequent demands on dry season labour, and the depth of links with other producers in this and neighbouring villages through which help may be sought.

The measures taken during the dry season will intensify the more widespread and sizeable the harvest failure. If only a few households have had a poor harvest, they can obtain a significant supplement to their stocks from grain distributed at harvest-time and from gifts made to women. In 1980 and 1981, the millet harvest in Kala was better than that in many other villages and, consequently, households in Kala received a stream of visitors at harvest-time and in the dry season that followed. In all, more than 80 men and women came to pass several weeks in Kala during the dry season of 1981. Most of these visitors were from settlements no more than $50 \mathrm{~km}$ away and they stayed with a household with whom they were able to establish some sort of kin link. Such links were often fairly distant; one man remarked that in years when his harvest had been a success, he got to know this more distantly related kin very much better.

In a year such as 1984 , when drought burned the millet crop of most villages in the region, by early September almost all young men had left to go to the cities as soon as it was clear that the harvest had failed. The start of the harvest in mid-October witnessed the movement by many women to the few villages whose crops had performed relatively well. These women planned to spend two or three months harvesting and winnowing grain and earning millet in return.

Thus, the highly localised distribution of rainfall in this region coupled with differences in soils and access to dung mean that harvests vary considerably from village to village in a single year. Shifts in population from grain deficit to surplus areas provide some access to food for those in need, while enabling those with large harvests to get the grain winnowed and stored with greater speed.

\section{Changing Strategies for Deficit Households}

Methods of coping with food shortage in this region have adapted to changing circumstances over the past couple of centuries. When Mungo Park travelled through the region in the $1790 \mathrm{~s}$, he noted the destitution of many families and the common practice of pawning a child to a richer neighbour in exchange for grain. The child eats with and works for his new family but will return home when his parents are able to redeem him by repaying the original sum. This 
system was quite widely practised even until fairly recently, a woman from one household in Kala having been pawned as a child during the difficult years of the 1930s.

The institution of domestic slavery povided cheap labour both to till fields and to carry out domestic tasks until its formal abolition in 1905. As the master was responsible for only some of the slave's food needs, owning slaves afforded some measure of protection from food shortages. A further means by which communities coped with harvest failure in the pre-colonial period was by raiding other villages. Huddled within an encircling mud wall, these villages tried to protect themselves from the threat of raids from stronger neighbours. However, the use of sieges and other tactics allowed local warlords to capture and plunder other settlements in a manner similar to the larger-scale military manoeuvres of the 18 th and 19 th century kings of Segou. One old man in Kala, interviewed by a colonial officer in the $1920 \mathrm{~s}$, described the difficulty they now faced, following the French conquest and pacification, as villages in need could no longer raise a force to supplement their reserves by seizing others' grain.

In the 1930s, a series of poor harvests coincided with annual invasions by locusts throughout this region. The collapse of world market prices for many traditional commodities, such as shea-nut butter and kapok fibre, badly hit villages in the Segou region who relied on the sale of these products for money with which to pay taxes. Harvest failure, tax demands and the requisitioning of grain forced people throughout the zone to sell assets and to earn money on migration. Refusal to pay taxes was sternly dealt with: on one occasion the administration rounded up and carried away all Kala's womenfolk, who were only released once the missing sum had been found. Both livestock and gold were sold during the 1930s to find the money for taxes. One Commandant of Segou noted a flood of gold had been traded in 1933-34 and he attributed this to the heavy pressure on villagers to meet tax payments in these years of penury. Several villagers from Kala told of the liquidation of their entire cattle holdings during this period in an attempt to raise cash.
Migration by young men became an important means to earn cash from the 1920 s onwards. Initially they travelled to the groundnut growing areas of western Mali and eastern Senegal and to the gold mining regions on the border between Mali and Guinea. Old men from Kala and neighbouring settlements can still intone the names of those villages through which they passed on the north-long trek to Senegal. The rising economic prosperity of Ivory Coast now attracts most of the young men from this region who plan to go on long distance migration.

\section{Conclusions}

Households in this region of marginal and high risk farming have long needed strategies for dealing with food shortage. Certain activities such as raiding can no longer be practised. Others such as migration have grown in importance. Households differ considerably in their ability to feed their members, the larger domestic groups being less vulnerable to chronic food shortages. These differences arise not only out of variation in the ownership of productive assets used in farming but also from differences in the household's ability to diversify its income-earning activities. The dry season is the main time available for such diversification. Grain deficit households must spend this season finding food for the farming season to come, whereas those in the larger grain surplus households can use the dry season to accummulate private sources of wealth. Redistribution of grain within the community remains of great importance to those who have suffered a poor harvest. People may try to limit the demands made upon them by importunate relatives, by converting surplus grain into livestock holdings, but the basic duty to provide hospitality and help to those in need continues to be a strong element within Bambara society.

\section{References}

Lewis, John van dusen, 1979, 'Descendants and Crops: Two Poles of Production in a Malian Peasant Village', $\mathrm{PhD}$ thesis, Department of Anthropology, Yale 